\title{
17. HIGH RESOLUTION RECORDS OF BENTHIC FORAMINIFERS IN THE LATE NEOGENE OF THE NORTHEASTERN ATLANTIC 1
}

\author{
Detmar Schnitker, University of Maine at Orono ${ }^{2}$
}

\begin{abstract}
Sediment composition and color, as well as faunal content of hydraulic piston cores of late Pliocene and Quaternary age from Deep Sea Drilling Project (DSDP) Hole 552A (Northeast Atlantic), show large and fairly regular variations. Based on paleontologically and paleomagnetically determined sedimentation rates, these variations occurred at about 100,000 -yr. intervals during the past 700,000 yr, and at approximately 40,000-yr. intervals between $700,000 \mathrm{yr}$. and 2.5 m.y. ago, the date of the first appearance of "glacial" (ice-rafted) sediments. These changes affected both surface and bottom waters of the area, as indicated by planktonic and benthic foraminifers.

However, sediments older than $2.5 \mathrm{~m}$.y. do not exhibit any obvious fluctuations in composition, nor does the fauna of planktonic foraminifers, which indicates that surface climate and oceanographic conditions were stable. On the other hand, the deep-water environment, as evidenced by the composition of benthic foraminiferal faunas, did not experience the sharp break at $2.5 \mathrm{~m}$.y. Faunal fluctuations of about 20,000-yr. periodicity extend continuously into the early Pliocene and late Miocene.

Formation of North Atlantic Deep Water occurs primarily in the Norwegian-Greenland Sea and its properties and rate of formation there are modulated during "glacial" time by surface climate, determined by eccentricity and obliquity orbital parameters. In "preglacial" times the midlatitude effect of the precession orbital parameter assumes greater significance.
\end{abstract}

\section{INTRODUCTION}

Benthic foraminifers contained in deep-sea sediments are but one recorder of the development of global and regional climates and their interaction with the ocean. To the extent that the ecological requirements or preferences of these organisms are known, they permit deductions about the past nature of the deep-sea environment and also of its change. But where such ecological information is unreliable or even lacking, faunal changes nevertheless track the timing and, to some extent, the amplitude of change.

Studies of North Atlantic deep-water benthic foraminifers (Streeter, 1973; Schnitker, 1974, 1979; Streeter and Shackleton, 1979) have demonstrated such close relationships between oceanic water masses and faunas and also the nature, magnitude, and timing of change that occurred in the deep-water environment in response to climatic change. These findings have recently been corroborated by independent, geochemical means (Boyle and Keigwin, 1982). The growth of Northern Hemisphere continental glaciers, accompanied by sea-ice cover of the northern North Atlantic, especially the Norwegian-Greenland Sea (Kellogg, 1976), and the southward shift of the North Atlantic Drift (CLIMAP, 1976) apparently find their corresponding expression in the deep sea. The drastically changed surface conditions led to the elimination of, or at least to a strong reduction in, the formation of deep and/or bottom water in the northern North Atlantic.

\footnotetext{
${ }^{1}$ Roberts, D. G., Schnitker, D., et al., Init. Repts. DSDP, 81: Washington (U.S. Govt. Roberts, D. G., Schnitker, D., et al., Init. Repts. DSDP, 81: Washington (U.S. Govt.
Printing Office).
2 Address: Department of Geological Sciences and Program of Oceanography, Univer-
sity of Maine at Orono, Orono, Maine 04573.
}

It can therefore be expected that similar restructuring of the deep-water circulation occurred during each of the many episodes of Northern Hemisphere glaciation that have so clearly inscribed themselves into the record of $\delta^{18} \mathrm{O}$ variations of oceanic microfossils (Emiliani, 1955; Shackleton and Opdyde, 1977).

On the other hand, a small body of observations exists that points to even earlier fluctuations of the marine environment. Savin et al. (1975) noted fairly regular fluctuations $\left(0.2-0.5 \%\right.$ ) of $\delta^{18} \mathrm{O}$ in early Miocene South Atlantic planktonic foraminifers; Schnitker (1979) found that North Atlantic deep-water foraminifers showed Quaternary-like faunal alternations beginning in the late Miocene; Dean et al. (1981) observed cyclical fluctuations of the carbonate content of Sierra Leone Rise sediments occurring during much of the Tertiary; and Moore et al. (1982) found fluctuations of the carbonate contents in late Miocene equatorial Pacific sediments.

Considering the significance of the northern North Atlantic to global oceanography and climate and also its sensitivity to change (Schnitker, 1980; Berggren and Schnitker, 1983), it should be expected that the "preglacial" fluctuations are present there as well; and a search for causal relationships for, and between, all observations might be appropriate. The nearly complete late Miocene to Recent record of DSDP Hole 552A provides the opportunity to test this expectation.

\section{MATERIALS AND METHODS}

The hydraulic piston cores of DSDP Hole 552A, raised from $2301 \mathrm{~m}$ depth west of Rockall Plateau $\left(56^{\circ} 02.56^{\prime} \mathrm{N}, 23^{\circ} 13.88^{\prime} \mathrm{W}\right)$, provided an almost complete sequence of upper Miocene to Recent sediments. The topmost $44 \mathrm{~m}$ of sediment (sedimentary Unit I; Cores 1-9) are characterized by alternating beds of light-colored calcareous ooze and tan-colored calcareous marls, clearly representing the history of ice rafting into the northeastern North Atlantic, and are thus a clear indi- 
cation of the development and course of northern Hemisphere glaciations. From 44 to 165 m (sedimentary Subunit IIa; Cores 10-34) no further alternations of sediment color and composition occur, the sediment being a relatively whitish foraminiferal nannofossil ooze.

For this study of the detailed behavior of the deep-water benthic faunas, five cores were sampled at $10-\mathrm{cm}$ intervals. These cores were chosen in part for their apparent high quality (little or no drilling disturbance) but mainly to represent (1) high amplitude, late glacial sedimentological and thus high oceanographic-climatological contrast (Core 3); (2) the transition from ice-free conditions to ice rafting (Cores 9 and 10); (3) an intermediate "preglacial" level (Core 19); and (4) an early "preglacial" level (Core 30). According to the biostratigraphic and paleomagnetic datums provided elsewhere in this volume (Site 552 chapter; Krumsiek; Zimmerman et al.), Core 3 is of late Pleistocene age ( $\sim 0.45$ to $\sim 0.70$ m.y. old), Cores 9 and 10 of late Pliocene age $(\sim 2.2$ to $\sim 2.9$ m.y. old), Core 19 of early Pliocene age ( $\sim 4.5$ to $\sim 4.8$ m.y. old), and Core 30 of late Miocene age ( $\sim 6.39$ to $\sim 6.58$ m.y. old) (Table 1).

For an appreciation of the overall evolution of the benthic faunas during this total time interval, one sample for about every $0.5-1.0$ m.y. from the Neogene sections of Holes 552A, 553, 554, and 555 were also investigated.

The samples, of approximately $15-\mathrm{cm}^{3}$ volume, were disaggregated in a weak Calgon solution and washed on nested sieves of $125 \mu \mathrm{m}$ and $63 \mu \mathrm{m}$ average opening. The $>125-\mu \mathrm{m}$ fraction of each sample yielded at least $\mathbf{2 0 0}$ specimens of benthic foraminifers, mostly many more. Although well over 140 species were separated from this material, the quantitative tallies were limited to 65 common and easily recognizable species or species groups (see Appendix).

The abundance of individual species was expressed as a percentage of the total benthic fauna. Although this relative measure of abun- dance does not reflect accurately the success or failure of an individual species and is therefore of some limited value in arriving at paleoecological interpretations, it nevertheless represents a precise measure of the timing and magnitude of environmental change.

The census data were subjected to a Q-mode varimax principal component analysis (Imbrie and Kipp, 1971), sorting them into groups of covariant species. For sample suites of relatively low faunal diversity, the first few principal components usually were an expression of the abundance fluctuations of the most dominant species. On the other hand, for sample suites of high faunal diversity and high equability, principal-component analysis succeeded in sorting out and quantifying faunal similarities and differences which otherwise would not have been easily detectable.

The techniques of power-spectrum analysis of Blackman and Tuckey (1958) were used, together with the time scales listed in Table 1, to estimate the periodicity and strength of the faunal fluctuations within the high resolution record of Cores $3,9,10,19$, and 30 .

\section{GEOGRAPHIC AND OCEANOGRAPHIC SETTING}

Hole 552A was drilled on the Hatton Drift, west of Rockall Plateau (Fig. 1). Hatton Drift is one of several elongate bodies of sediment in the northern North Atlantic whose genesis is thought to be closely related to the activities of deep bottom currents (Jones et al., 1970; Ruddiman, 1972; Roberts, 1975) and which date back to at least the middle or early Miocene (Shor and Poore, 1979). The deep bottom currents flowing clock-

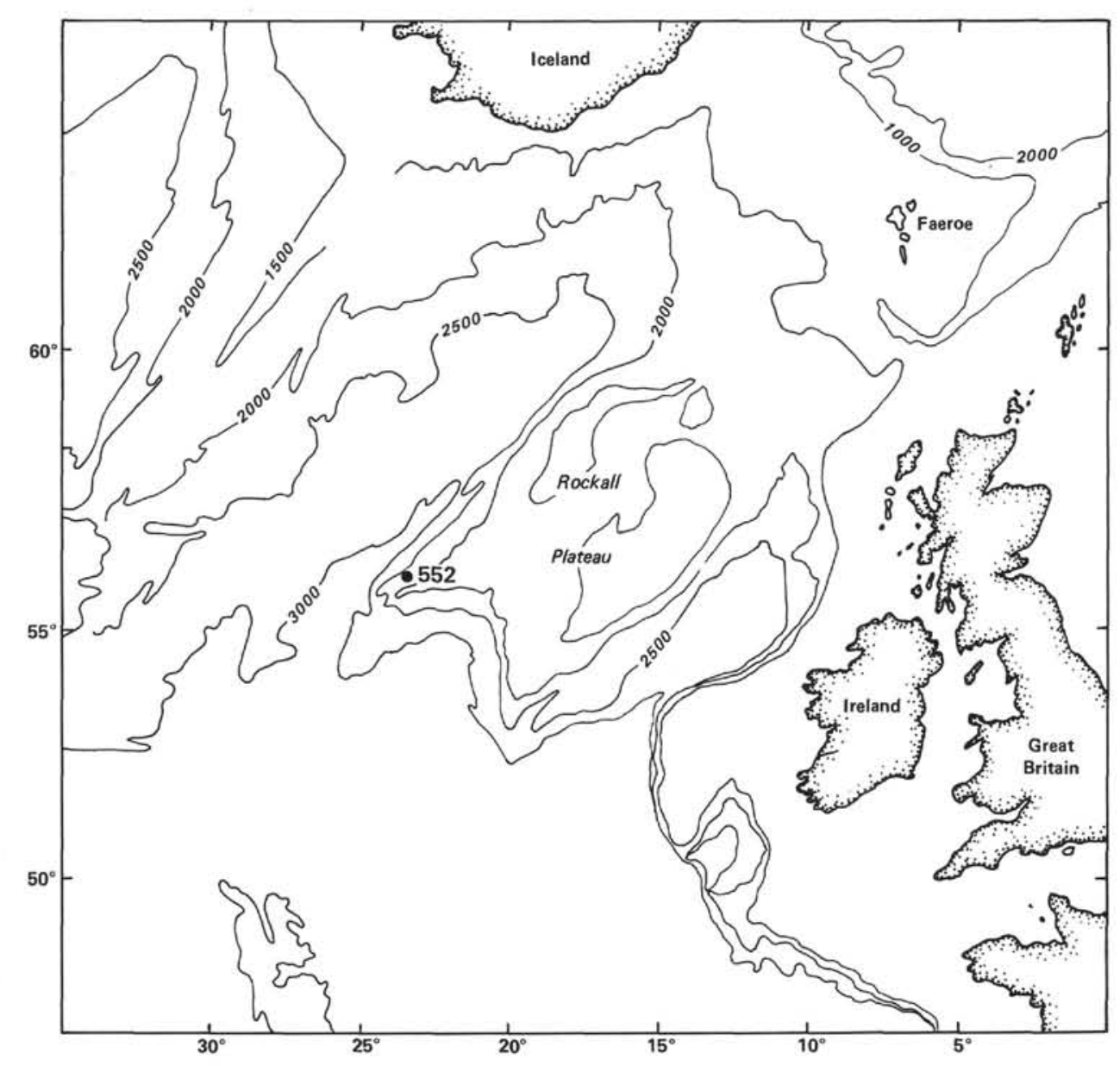

Figure 1. Location of DSDP Site 552, northeast Atlantic. 
wise around Rockall Plateau are essentially driven by overflow from the Norwegian Sea through the Faeroe Bank Channel. During its descent into Rockall Trough and along its flow path, the Norwegian Sea Overflow entrains warmer and less saline water of Labrador Sea origin (Ellett and Roberts, 1973; Lonsdale and Hollister, 1979). According to the charts of Worthington and Wright (1970) this bottom water has a salinity of about $34.96 \%$, a potential temperature of $3.3^{\circ} \mathrm{C}$, and an oxygen content of about $6.1 \mathrm{ml} / 1$.

\section{RESULTS}

\section{The Neogene Succession}

To provide a background of the general benthic faunal evolution of the Neogene section of the western Rockall Plateau margin, the faunal census data of three sites, $552 \mathrm{~A}, 553$, and 554, were combined and subjected directly to a Q-mode varimax principal-component analysis. This analysis sorted out five faunal groupings which account for $93 \%$ of the total information. These groupings can be arranged in stratigraphic succession as follows:

1. A late Oligocene to early Miocene assemblage, accounting for $24 \%$ of total variability, which is strongly dominated by Alabamina sp. and with Globocassidulina subglobosa and Oridorsalis umbonatus as prominent accessory species.

2. An early Miocene to early middle Miocene assemblage, accounting for $19 \%$ of total variability, which is very strongly dominated by Stilostomella spp. and $O r$ thomorphina spp. and to a lesser extent by Bulimina alazanensis.

3. A middle Miocene assemblage, accounting for $24 \%$ of total variability, which is dominated by Pullenia bulloides, Melonis barleeanum, Planulina wuellerstorfi, and $O$. umbonatus, all in nearly equal proportions.

4. A late Miocene and early Pliocene assemblage, accounting for $15 \%$ of total variability, which is strongly dominated by Epistominella exigua and with $P$. wuellerstorfi, Ehrenbergina spp., and G. subglobosa as prominent accessory species.

5. A late Pliocene and Pleistocene assemblage, accounting for $10 \%$ of total variability, which is dominated by Triloculina frigida and Cassidulina teretis, with Pullenia quinqueloba, M. pompilioides, and $O$. tener as prominent accessory species.

Although most benthic species range throughout the Neogene section, the quantitative faunal composition, and by inference the northeast Atlantic environment, changed considerably through time. The strongest change came about at the beginning of the middle Miocene. It was roughly at this time that several of the Paleogene "survivor" species became extinct, namely Siphonina tenuicarinata, Alabamina sp., Anomalinoides sp., and Planulina sp., a precursor to $P$. wuellerstorfi. Likewise, several of the most distinctive species of the modern deep-sea environment made their first appearance: Epistominella exigua, $M$. pompilioides, and $P$. wuellerstorfi. It is not sure whether all of these disappearances and appearances of species are true extinctions and speciations. For exam- ple, $E$. exigua has been reported from Oligocene deposits (Boltovskoy, 1980); M. pompilioides has been reported as early as the late Eocene, but not from truly deep-water deposits. It appears that this species invaded the abyssal environment only in the middle Miocene, having reached bathyal environments (i.e., the top of Rockall Plateau, Sites 116,555$)$ by early Miocene time.

\section{The High Resolution Record}

To relate the occurrence of benthic species, and thus deep-water paleoceanography, to surface water paleoceanography and climate, a quick census of the incidence of ice-rafted detritus and of the abundance of Neogloboquadrina pachyderma, a cold-water species of planktonic foraminifer, was executed on each sample. The resulting curves (Fig. 2) give a very clear indication of the successive glacial and interglacial episodes and possibly also a measure of their relative intensities.

\section{Core 3-Late Pleistocene}

This core exhibits faunal variability of the kind and magnitude that has been observed elsewhere in late Quaternary piston cores (Streeter and Shackleton, 1979; Schnitker, 1979; Corliss, 1979) or in Pleistocene DSDP cores (Lutze, 1979). Only about 10 species occur with $>5 \%$ average abundance and attain peak abundances of $>10 \%$ at least at one level within the core.

Epistominella exigua and to a lesser extent Melonis barleeanum and $M$. pompilioides comprise the species that tend to reach their greatest relative abundances during interglacial episodes (Fig. 3). E. exigua, which in the present North Atlantic is invariably associated with "young," well-oxygenated bottom water (Norwegian Sea Overflow-North Atlantic Deep Water) (Schnitker, 1980), dominates the interglacial episodes of Core 3 . This pattern suggests that bottom-water production and circulation, particularly during the long interglacial episode around 0.5 m.y. ago $(9.70-10.70 \mathrm{~m})$, operated in a similar fashion to that of today. On the other hand, $M$. barleeanum shows only a minor increase during the upper interglacial episode but sharply increases during the lower interglacial episode, about 0.64 m.y. ago (12.70$13.00 \mathrm{~m})$. M. pompilioides appears to respond most uniformly to the glacial-interglacial alternations; unfortunately its relatively low abundance somewhat restricts its value as an indicator species.

Cassidulina teretis, Triloculina frigida, Astrononion echolsi, and Oridorsalis tener are the dominant species during glacial episodes (Fig. 3). These species, too, do not react uniformly to the glacial-interglacial alternations. $C$. teretis reaches its greatest abundances at the uppermost two glacial episodes, at $9.60 \mathrm{~m}(\sim 0.46 \mathrm{~m}$.y. ago) and at $10.90-11.10 \mathrm{~m}(\sim 0.55 \mathrm{~m} . \mathrm{y}$. ago); it fails to react to the lower two glacial episodes of Core 3. T. frigida clearly tracks only the long glacial episode, including its tripartite fine structure, from 10.80 to $12.10 \mathrm{~m}$ (from $\sim 0.54$ to $\sim 0.605 \mathrm{~m}$.y. ago). It provides no indication for either the uppermost or lowest glacial episodes. $O$. tener occurs in low abundance, or is absent, from 9.50 to $11.00 \mathrm{~m}$, rising gradually to a peak of $30 \%$ 

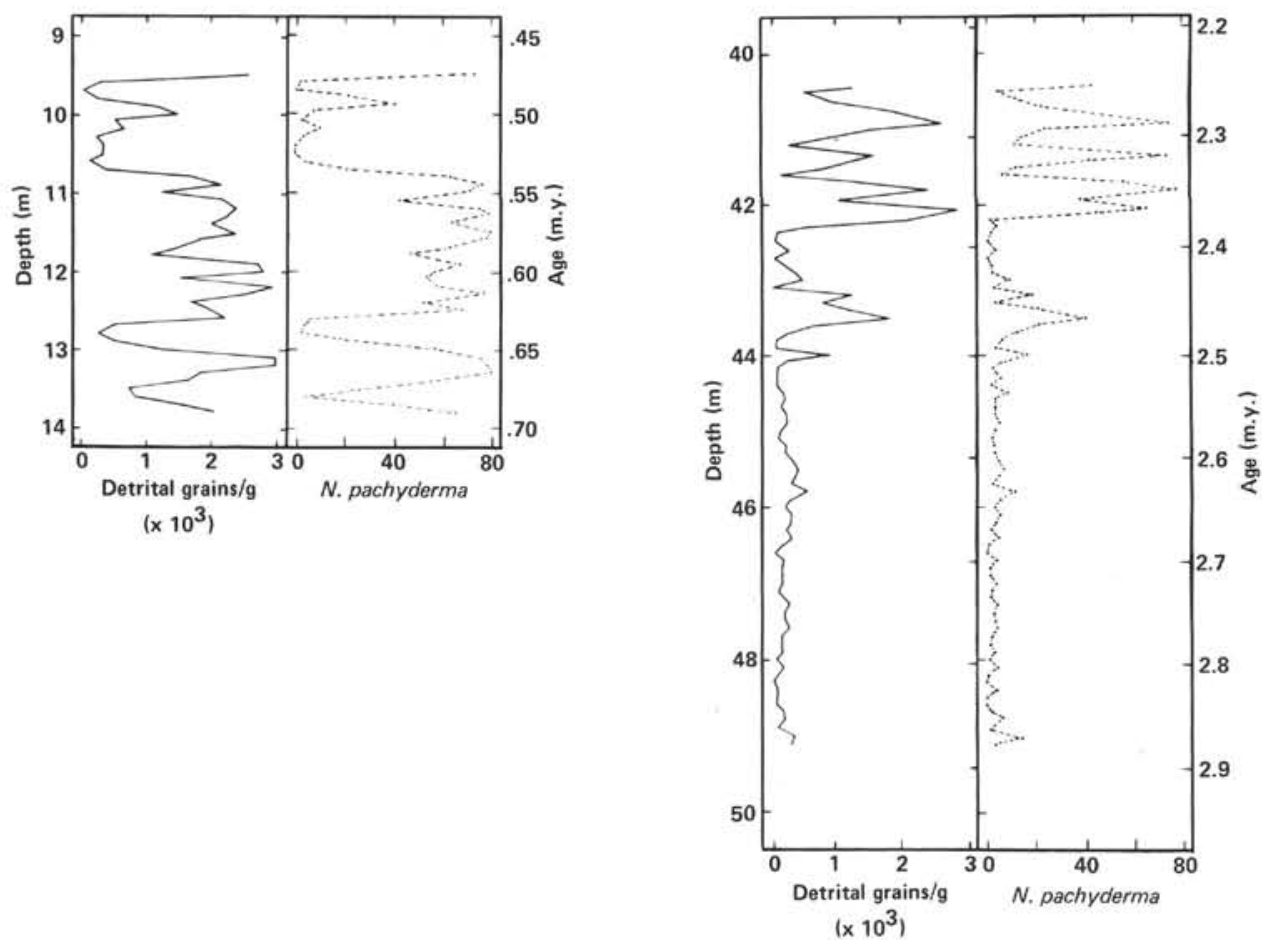

Figure 2. Occurrence of Neogloboquadrina pachyderma (left and right coiled), a cold-water species of planktonic foraminifer, and coarse $(>150 \mu \mathrm{m})$ terrigenous detrital grains, presumably ice rafted.

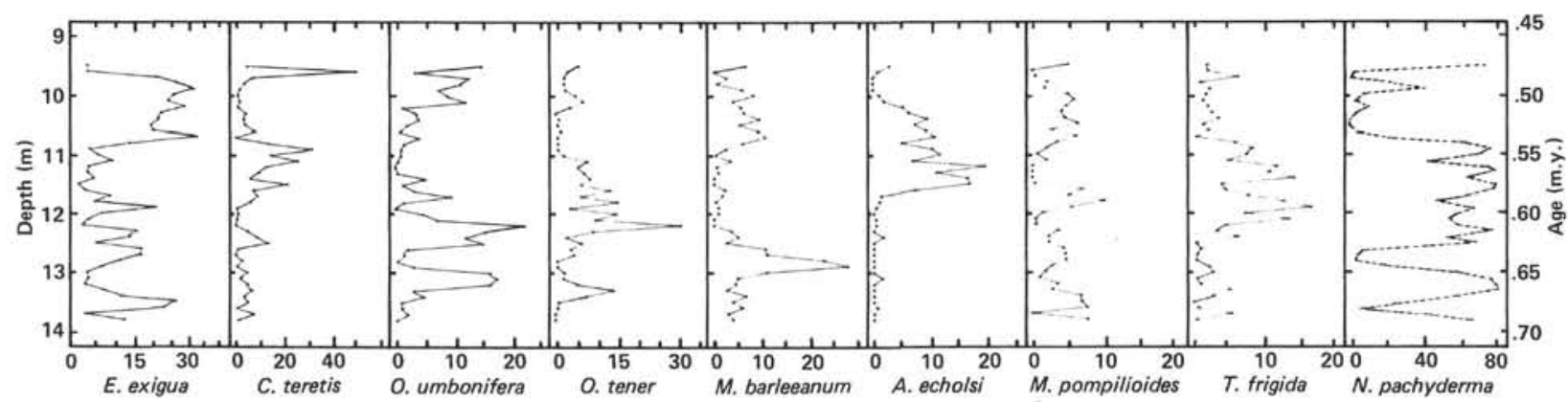

Figure 3. Abundance fluctuations within Core 3 (late Pleistocene) of eight common benthic foraminiferal species and the cold-water planktonic species $N$. pachyderma.

during the glacial episode from 11.00 to $12.20 \mathrm{~m}(\sim 0.56$ to $\sim 0.61$ m.y. ago) and rising again to a lesser peak at the glacial episode at $13.30 \mathrm{~m}(\sim 0.665 \mathrm{~m} . \mathrm{y}$. ago).

The abundance peaks of the remaining common species, Osangularia umbonifera, Eggerella bradyi, and Pullenia quinqueloba, are not centered on either glacial or interglacial episodes but rather upon the transitions from one state to the other (Fig. 3).

The occurrence of Epistominella exigua and M. pompilioides during interglacial episodes of Core 3 is largely in concordance with observations in cores elsewhere in the North Atlantic, whereas the interglacial occurrence in Core 3 of $M$. barleeanum is the opposite to that observed by Streeter and Shackleton (1979) in Core V29. 179 , where $M$. barleeanum peaks during oxygen isotope Stage 2, the deepest glacial episode. Similarly, the occurrence of $A$. echolsi and Oridorsalis tener during glacial episodes of Core 3 is in concordance with observations elsewhere. The occurrence of $C$. teretis and $T$. fri- gida appears to be a phenomenon restricted to the north€astern North Atlantic. Belanger (1981) reports these species from the Iceland-Faeroe Ridge and the Norwegian Sea. Most notable, however, is the nearly complete absence of Uvigerina peregrina from Core 3, particularly during glacial episodes, when it becomes the dominant species in cores south of the glacial-stage polar front.

That different species characterize successive glacial and interglacial episodes leads to two possible explanations: (1) the ecological requirements and preferences of foraminiferal species are not constant or (2) the bottomwater characteristics of the successive glacial and interglacial circulation regimes were not strictly repetitive but differed somewhat from each other. Although it may be possible that different climax communities form under identical environmental conditions through interspecific competition and exclusion, it is probably safer to assume that the bottom-water characteristics varied slight- 
ly through the successions of glacial and interglacial regimes. In view of the variability of the surface climate and oceanography, as expressed by the ice-rafted detritus and planktonic foraminifers, no two glacial or interglacial episodes were exactly alike; the assumption of bottom-water variability appears reasonable as well.

Q-mode prinicipal-component (pc) analysis grouped the census data into six assemblages, which together accounted for $90 \%$ of the faunal variability (Fig. 4). These assemblages are dominated by single species: PC I by $E$. exigua; PC II by $C$. teretis; PC III by Osangularia umbonifera; PC IV by Oridorsalis tener; and PC V by $M$. barleeanum. PC VI has $A$. echolsi as principal species with $T$. frigida subdominant. Consequently, these principal components correlate to the sequencing of glacial and interglacial episodes of the nominal species, with additional fine structure from the subordinate covariant species.

Measuring the regularity of these faunal fluctuations depends critically on the accuracy of the time scale employed. Even if the time-control points (Table 1) are correct, considerable inaccuracies can be introduced into the time scale by variations of the sediment-accumulation rates. Since the accumulation of sediment is in itself dependent on oceanographic and climatic conditions (i.e., productivity of planktonic organisms, influx of terrestrial detritus, especially ice rafting), variable sedimentation rates are probably the rule rather than the exception. If, as is expected here, the periodicities of orbital-parameter variations are present in this record, at least in its upper portion, then it is particularly the highfrequency component that has deteriorated the most. Hays et al. (1976) and Moore et al. (1982) have demonstrated the use and utility of correcting time scales by tuning observed perodicities to the record of calculated periodicities of orbital-parameter variation. By tuning to one of the more readily recognizable periodicities of the observed spectrum, the resulting improvement in the accuracy of the time scale usually led to sharper resolution of the other orbital frequencies as well.

Such tuning could not yet be performed on the records from Hole 552A; however, a first and straightforward assessment of their frequency content appears use-
Table 1. Age-depth calibration points utilized for determination of time scale for Hole 522A.

\begin{tabular}{rcl}
\hline $\begin{array}{c}\text { Depth } \\
(\mathrm{m})\end{array}$ & $\begin{array}{c}\text { Age } \\
(\mathrm{m} . \mathrm{y} .)\end{array}$ & \multicolumn{1}{c}{ Event } \\
\hline 0.00 & 0.00 & \\
14.60 & 0.73 & Brunhes/Matuyama \\
32.20 & 1.66 & Top of Olduvai \\
56.60 & 3.40 & Gauss/Gilbert \\
133.50 & 6.20 & F.O. of $T$. convexa \\
\hline
\end{tabular}

Note: Data were selected from Krumsiek; Zimmerman et al.; and Site 552 chapter; all in this volume.

ful, particularly when keeping in mind that the records, as presented here, probably suffer significantly from time-scale inaccuracies. Although few of the spectral peaks attained statistical significance, it should be noted that they usually occurred at or near the orbital frequencies and also that they were usually the only peaks present.

Based on a linear interpolation between zero age at the seafloor and $0.73 \mathrm{~m}$.y. at $14.60 \mathrm{~m}$, the Brunhes/Matuyama boundary, visual checks for any regularity in the succession of peaks and valleys of the factor loadings can be made, as well as tentative spectral analyses.

PC I displays several good peak-to-peak and valleyto-valley matches at very close to 40,000 yr. intervals, with a few of them bisected by intermediate $(20,000$-yr.) peaks and valleys. Spectral analysis reveals peaks at $\sim 133,000-, 40,000-$, and 20,000-yr. periodicities, none of them significant at the $80 \%$ confidence level.

PC II does not display any easily recognizable periodicities; spectral analysis reveals a high at a $\sim 133,000$ yr. periodicity, which is not significant at the $80 \%$ confidence level.

PC III shows three clear and deep cycles of 40,000-yr. length within the lower half of the record; in the upper half these cycles become shallower and somewhat less regular, shorter in one case, longer in the other. These variations in cycle length probably reflect variable sedimentation rates. Spectral analysis shows a distinct and

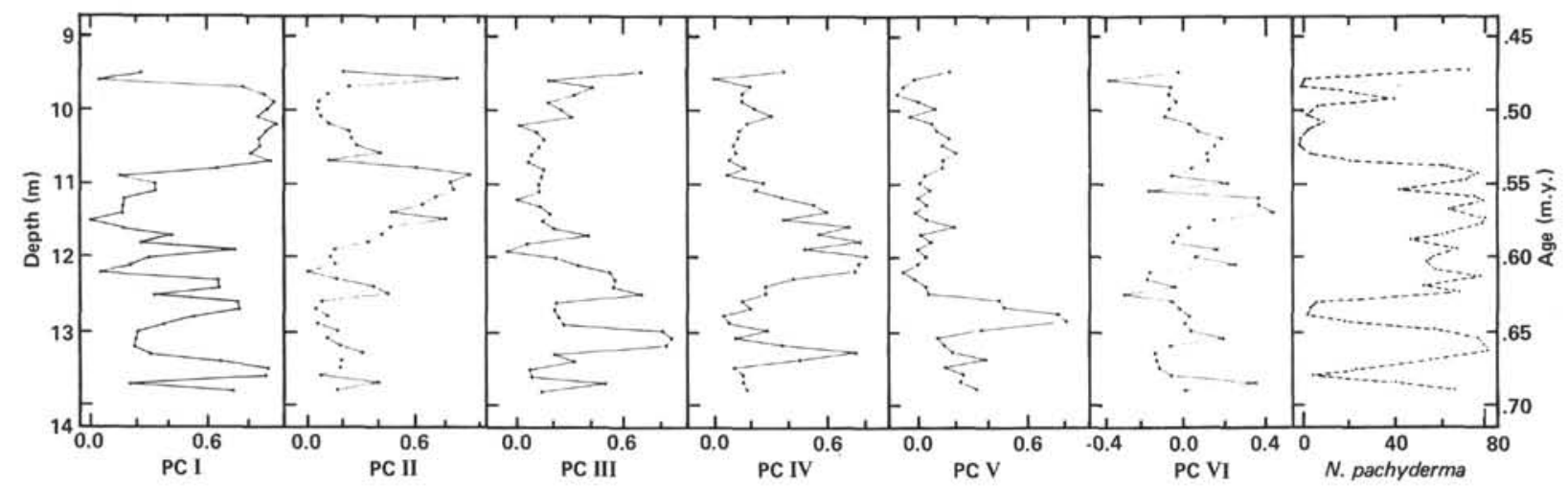

Figure 4. Fluctuations of principal-component loadings representing six faunal associations of benthic foraminifers within Core 3 (late Pleistocene) compared with surface-water conditions indicated by the relative abundance of the cold-water species $N$. pachyderma. 
significant peak (at the $80 \%$ confidence level) at a period of $40,000 \mathrm{yr}$.

PC IV does not exhibit any easily recognizable periodicities, although a broad sweep of about 60,000 -yr. wavelength underlies the irregular high-frequency fluctuations. Spectral analysis shows only an insignificant peak (at the $80 \%$ confidence level) at a 200,000 -yr. period.

PC V essentially displays only the single strong abundance peak of its principal species ( $M$. barleeanum) at $12.90 \mathrm{~m}$; no regular behavior of the factor loadings is recognizable, neither by inspection nor by spectral analysis.

PC VI exhibits fairly good peak-to-peak and valleyto-valley matches at about 40,000-yr. intervals; spectral analysis reveals a sharp peak at the 40,000 -yr. period, which does not quite reach the $80 \%$ confidence level.

The length of the total record of Core $3, \sim 215,000$ yr., is insufficient to reveal unambiguously long periodicities, although a period of greater than $100,000 \mathrm{yr}$. in length is strongly suggested. On the other hand, a periodicity of approximately 40,000 yr. is clearly embedded in the faunal record, with a faint suggestion of a 20,000yr. periodicity as well (Fig. 5).

\section{Cores 9 and 10-Late Pliocene}

Cores 9 and 10 straddle an important oceanographic and climatological transition, which is marked in Hole $552 \mathrm{~A}$ by the beginning of cyclical appearances of icerafted detritus and cold-water planktonic foraminifers at $44 \mathrm{~m}(\sim 2.5 \mathrm{~m} . \mathrm{y}$. ago) at the bottom of Core 9 (Fig. 6). The sharp changes that many species of deep-water benthic foraminifers undergo at the same time indicate that the drastic climatic and oceanographic transition affected the deep-water sphere as well.

Among the dozen most abundant species, some decreased sharply in their abundance at the transition level (e.g., Pullenia bulloides, Oridorsalis umbonatus, Astrononion echolsi), while a small, slender species of Hopkinsina (probably Uvigerina compressa Cushman in Murray, this volume) disappears completely at the 44-m level. Other species increased significantly in their abundance at the transition level (e.g., Eggerella bradyi, Glo-
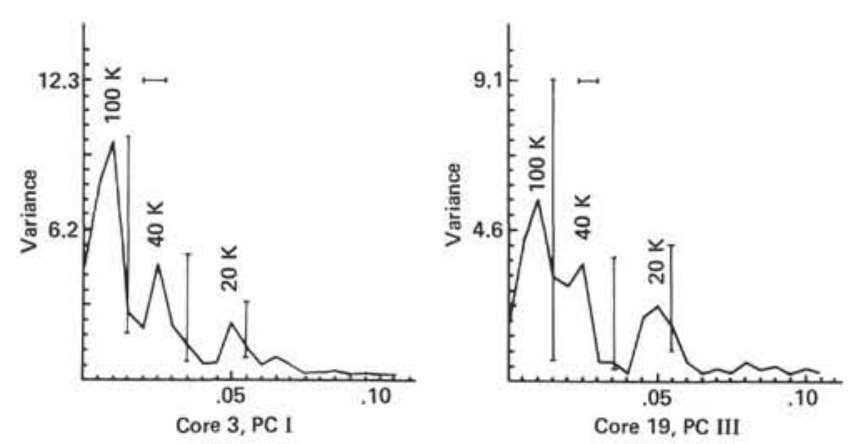

Figure 5. Representative variance spectra of faunal variation within Cores 3 and 19. Note the absence of variance concentration at other than the orbital parameter variation periodicities. The vertical bars give the $80 \%$ confidence intervals for the spectral estimates, the horizontal bars give the band width used in spectral analyses. bocassidulina subglobosa) or essentially appear there for the first time (Cassidulina teretis).

While the first occurrence of ice-rafted detritus and cold-water planktonic foraminifers and the strongest response by the benthic foraminifers lies at the 44-m level, the glacial episode above the $42-\mathrm{m}$ level appears to have been extraordinarily deep. Several species of benthic foraminifers react to this event in a steplike fashion very similar to the reaction at the 44-m level event. For example, Bulimina alazanensis disappears, C. teretis and Gyroidinoides orbicularis decrease sharply, while $E$. bradyi, P. quinqueloba, Stilostomella spp., and Globocassidulina subglobosa become greatly more abundant above the $42-\mathrm{m}$ level.

Overall, the quantitative faunal composition of Cores 9 and 10 differs significantly from that of Core 3 . Species that were among the most abundant, even dominant, within the Core 3 faunas are either absent (Triloculina frigida) or very subordinate in Cores 9 and 10 (Epistominella exigua, Melonis barleeanum, Osangularia umbonifera). Other species are much more abundant in Cores 9 and 10 than in Core 3 (G. subglobosa, Planulina wuellerstorfi, Stilostomella spp.).

Superimposed on these general faunal trends are, again, rapid abundance fluctuations of most species, very much like the fluctuations described for Core 3 . As in Core 3, these abundance fluctuations in Core 9 follow the sequence of glacial and interglacial episodes, as expressed by the occurrence of ice-rafted detritus and cold-water planktonic foraminifers. Stilostomella spp., Eggerella bradyi, and $M$. pompilioides are the principal species that reach their greatest relative abundances during interglacial episodes (Fig. 6). G. subglobosa and Pullenia quinqueloba are the two common species that most clearly display their greatest relative abundances during the glacial episodes of Core 9. C. teretis likewise reaches its greatest abundances during the glacial episodes of Core 9 , but curiously disappears again above the 41.20-m level (Fig. 6).

Several other species seemingly fall into one or the other category (glacial or interglacial perference) as well, but because of their relatively low abundances are not considered here individually. As in Core 3, the amplitude of abundance peaks and valleys of the different species of Core 9 do not remain proportional through the successive glacial and interglacial episodes, again suggesting that bottom-water characteristics were not exactly repetitive through these cycles. Slight phase differences in the abundance peaks and valleys of many species can also be noted: Some species prefer the early, others the late phase of a particular climatic and oceanographic state.

Below Core $9(44 \mathrm{~m})$ ice-rafted detritus occurs only sporadically and in minute quantities and the fauna of planktonic foraminifers contains only few cold-water specimens. Thus prior to 2.5 m.y. ago the northeastern North Atlantic surface environment was apparently in a stable and relatively warm state. While many species of benthic foraminifers react strongly to this change of climatic and oceanographic state, as described earlier, many others do not react, or only slightly so. Most 


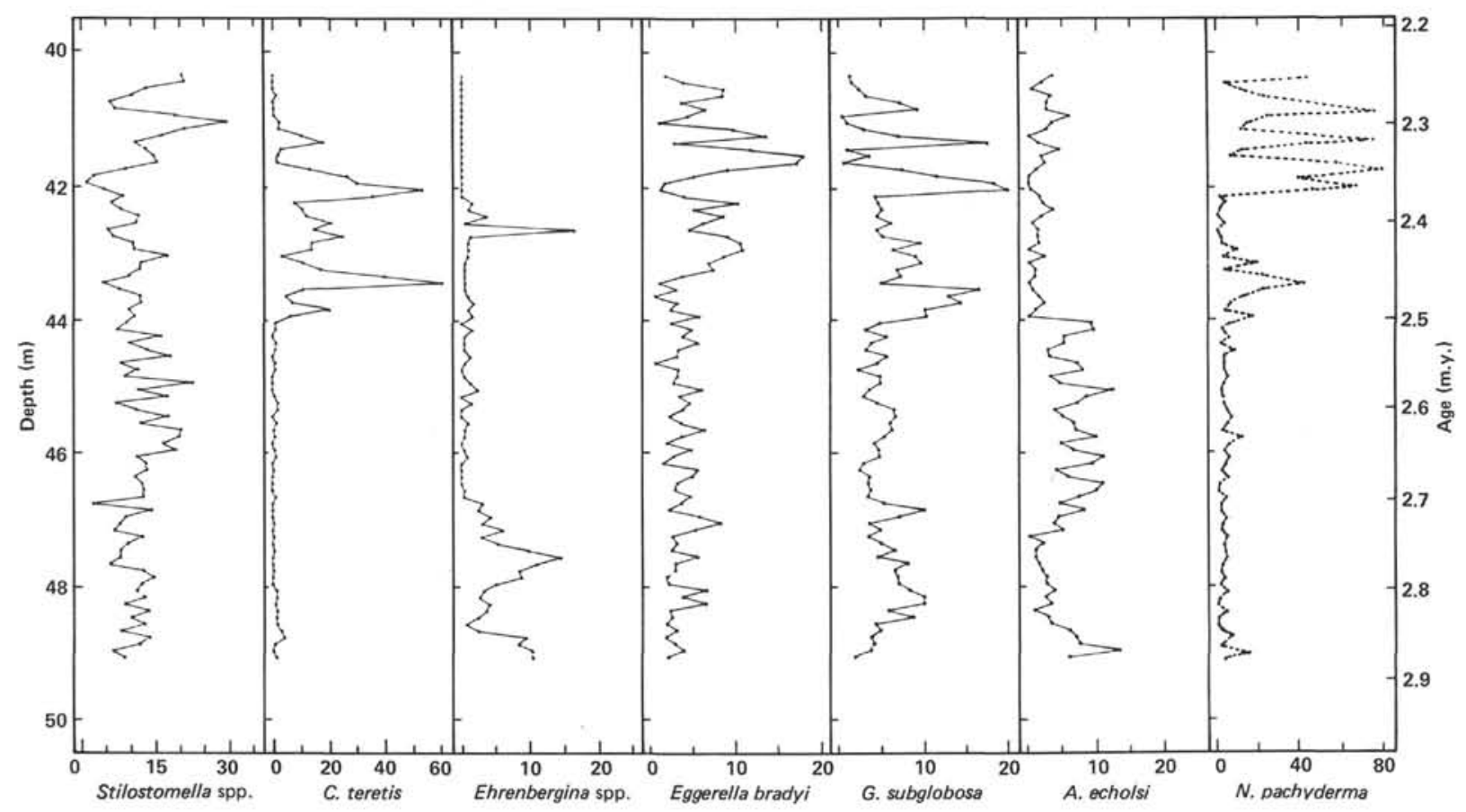

Figure 6. Downcore abundance fluctuations (Cores 9 and 10-late Pliocene) of six common benthic foraminiferal species and the coldwater planktonic species $N$. pachyderma. Note the first occurrence of cold surface environments (also manifested by ice-rafted detritus-not shown here) at $44 \mathrm{~m}, \sim 2.5 \mathrm{~m}$.y. ago.

noteworthy is that abundance fluctuations of the kind that were accompanying the glacial-interglacial indicator fluctuations in Cores 3 and 9 continue for many species below the 44-m level as well, although usually with somewhat reduced amplitudes.

Q-mode varimax principal-component analysis sorted the census data of Cores 9 and 10 into six assem- blages of covarying species, which together account for $87 \%$ of the total faunal variability (Fig. 7). Single-species dominance and differentiation of the faunas within Cores 9 and 10 is not as highly developed as in the late Pleistocene of Core 3. PC I is strongly dominated by Stilostomella spp.; PC II by C. teretis; PC III by Ehrenbergina spp. with Planulina wuellerstorfi making also a

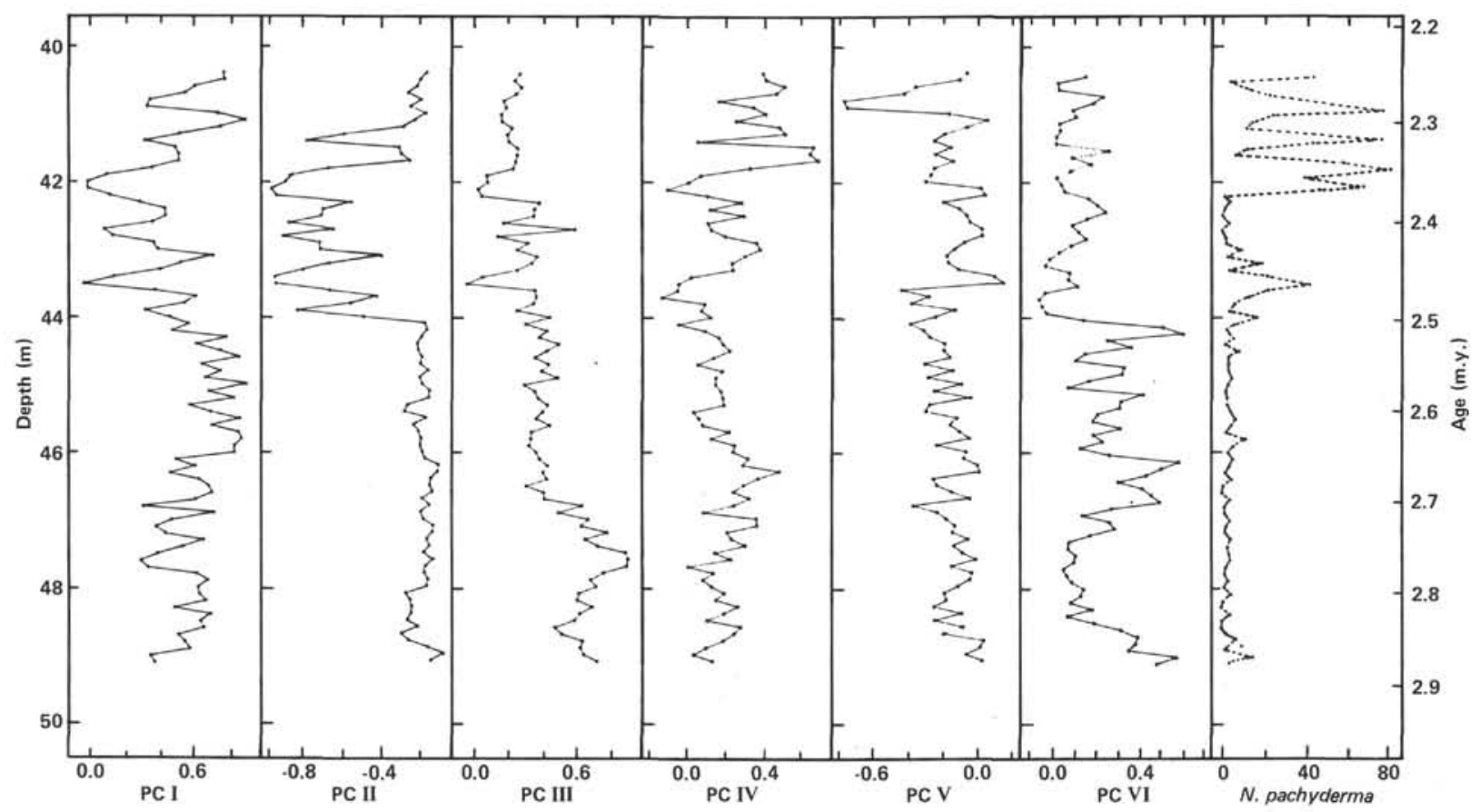

Figure 7. Fluctuations of principal-component loadings representing six faunal associations of benthic foraminifers within Cores 9 and 10 (late Pliocene). The abundance of the cold-water planktonic species $N$. pachyderma indicates surface conditions. 
highly significant contribution; PC IV by Eggerella bra$d y i$ with Epistominella exigua and $M$. pompilioides as significant subsidiary species; PC V by Oridorsalis tener with Pullenia quinqueloba and G. subglobosa nearly equally subdominant; and PC VI by $A$. echolsi with $O$. umbonatus and $E$. exigua being significant contributors.

One of the results of the Q-mode principal-component analysis was a sorting of species into those that are most abundant above the 44-m level (PC II and IV) and those most abundant in Core 10, below the 44-m level (PC V and VI). However, with the exception of PC II, which shows very little variability below $44 \mathrm{~m}$, all principal components clearly demonstrate more or less significant fluctuations of their loadings below the 44-m level as well as above it. Therefore, the faunal record of deepwater benthic foraminifers of Cores 9 and 10 appears to be much closer to the oxygen isotopic record of equatorial Pacific Core V28-179 (Shackleton and Opdyke, 1977) than the local record (Zimmerman et al., this volume). The deep Pacific record also shows regular variability, although with decreasing amplitude, for at least $1 \mathrm{~m}$.y. prior to a distinct change $\sim 2.5$ m.y. ago.

To estimate the approximate periodicity of the observed faunal variability, top and bottom ages for Cores 9 and 10 were derived by linear interpolation between the top of the Olduvai (1.66 m.y. ago) at $32.20 \mathrm{~m}$, the Matuyama/Gauss boundary 2.47 m.y. ago at $43.30 \mathrm{~m}$, and the Gauss/Gilbert boundary (3.4 m.y. ago) at 65.60 $\mathrm{m}$.

Because of the great dichotomy of the faunal records between the "preglacial" and "glacial" states, spectral analysis failed in all but one case to point to any coherent behavior of faunal fluctuations. Separate analyses for each core would probably have produced clearer results.

PC I displays several deep cycles above the 44-m level which appear to be approximately 40,000 to $45,000 \mathrm{yr}$. in length. From 44 to $45.80 \mathrm{~m}$ only single-point peaks and valleys of very low amplitude occur; below that level are low-amplitude peaks and valleys, alternating between about 20,000 and 40,000 yr. to 45,000 yr. duration. Superimposed is a general sinusoidal trend of high loadings at around $40.40 \mathrm{~m}(\sim 2.25 \mathrm{~m}$.y. ago), low loadings at $42.70(\sim 2.4 \mathrm{~m} . \mathrm{y}$. ago), high loadings at $45.00 \mathrm{~m}$ ( $\sim 2.6 \mathrm{~m} . \mathrm{y}$. ago), low loadings at $47.70 \mathrm{~m}(\sim 2.8 \mathrm{~m} . \mathrm{y}$. ago), thus representing a cycle with a length of roughly 400,000 yr.

PC II attains significance only between 41.20 and $44.10 \mathrm{~m}$. In this interval of approximately 200,000 -yr. duration, five high-amplitude fluctuations occur which range from 35,000 to 45,000 yr. in length. Below 44.10 $\mathrm{m}$ the principal component loadings remain fairly constant.

PC III does not display any easily recognizable periodicities but only a gradual decrease.

PC IV exhibits several high-amplitude fluctuations above the 44-m level of which the top four are of close to 40,000 -yr. duration. Below, the fluctuations become either too irregular or of too low an amplitude to be adequately gauged. Similar to PC I, PC IV also has a si- nusoidal trend of approximately 400,000 -yr. cycle length superimposed upon the high-frequency oscillations.

PC V consists of a few high-amplitude peaks but otherwise mostly of low-amplitude oscillations that display two long runs of 35,000 -yr. to 45,000 -yr. cycles, both above and below the $-44 \mathrm{~m}$ level. Spectral analysis indicates a significant (at the $80 \%$ confidence level) concentration of variance at periodicities of 100,000 and $20,000 \mathrm{yr}$. and an almost significant peak at a 40,000 -yr. period.

PC VI appears to contain four 60,000-yr. peak-topeak matches above the 44-m level and nine peak-topeak matches of 35,000-yr. to 40,000 -yr. duration below the 44-m level.

\section{Core 19-Early Pliocene}

Judging from the scarcity of cold-water planktonic foraminifers and the absence of ice-rafted detritus in Core 19, the early Pliocene northeast North Atlantic surface environment was stable and relatively warm. Yet, the record of benthic foraminifers suggests a still high degree of variability of the deep-water environment. In contrast to the benthic foraminiferal faunas of Cores 3 and 9, the composition of benthic faunas in Core 19 is much more equable: About a dozen species attain relative abundances varying between about 5 and $10 \%$, but none ever reaches the degree of dominance that several species assumed during the "glacial-interglacial" successions. In comparison with Core 10, the uppermost "preglacial" core, many species gain significantly in relative abundance, most notably Bulimina alazanensis, Cibicidoides kullenbergi, Ehrenbergina spp., Gyroidinoides neosoldanii, Hopkinsina sp., and Siphotextularia sp.; whereas Astrononion echolsi, Melonis pompilioides, and Pullenia quinqueloba are drastically reduced. Of all the species that in Cores 3 and 9 were associated with glacial episodes, only Globocassidulina subglobosa is present in Core 19 with significant relative abundance. It is therefore no longer appropriate to refer to the faunal variability of Core 19 in terms of "glacialinterglacial" successions, although the variability is strongly reminiscent of the variability displayed by Cores 3,9 , and 10 . The faunas are composed of "interglacial" and "preglacial" species.

Q-mode varimax principal-component analysis extracted six faunal associations which together account for $90 \%$ of total faunal variability. Three PCs (I, II, and VI) group species that are also abundant and/or significant during interglacial episodes in Cores 3, 9, and 10; PCs III, IV, and V are predominantly assembled from species which have reached significance, or have their last appearance in Core 19 (Fig. 8).

PC I, dominated by Stilostomella spp. with Epistominella exigua as significant accessory species, declines monotonically from the bottom of Core 19 to the top. In addition to this overall trend, PC I shows rapid oscillations that display a primary 40,000-yr. periodicity, with common appearances of 20,000-yr. peak-to-peak separations. Spectral analysis displays peaks at 200,000 yr. and 40,000-yr. periods which are not quite significant at the $80 \%$ confidence level. 


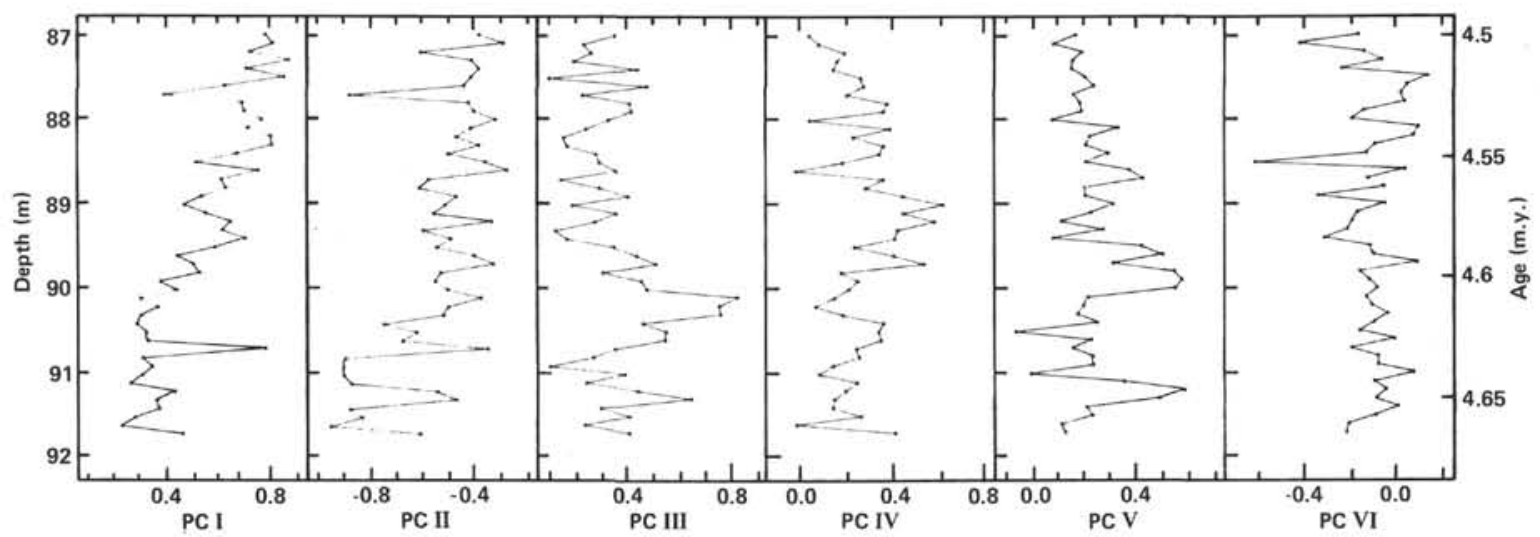

Figure 8. Downcore fluctuations of principal-component loadings representing six faunal associations within Core 19 (early Pliocene).

PC II, grouping principally Planulina wuellerstorfi, Gyroidinoides neosoldanii, M. barleeanum, and Eggerella bradyi, shows an overall increase with depth. The fluctuations of the principal-component loadings form a continuous sequence of cycles, each of slightly less than 20,000-yr. duration. Spectral analysis reveals a significant peak at 100,000 -yr. periodicity and a strong high at 18,000 -yr. periodicity which is not quite significant at the $80 \%$ confidence level.

PC III has B. alazanensis and Ehrenbergina spp. as nearly co-equal principal components with several other fairly significant accessory species. PC III displays a quite regular succession of valleys that are close to 20,000 yr. apart. Spectral analysis indicates a concentration of variance at a 20,000 -yr. period but which is not significant at the $80 \%$ confidence level.

PC IV, with Siphotextularia sp. and C. kullenbergi as its principal species, is dominated by three high-amplitude cycles each of slightly over 50,000-yr. duration, and each in turn is roughly divided in half by a lesser cycle. Spectral analysis shows the presence of variance concentration at 200,000,50,000 and 25,000-yr. periodicities, none significant at the $80 \%$ confidence level.

PC V is dominated by $G$. neosoldanii, with Hopkinsina sp. and Ehrenbergina spp. as accessory species. Although spectral analysis suggests a 50,000-yr. periodicity, only two such cycles, not very well defined, can be recognized. Higher frequency variations are not stationary, varying from 25,000 to $15,000 \mathrm{yr}$. in length.

PC VI, composed principally of Epistominella exig$u a$ and several nearly co-equal accessory species, displays only a short sequence of regular peak-to-peak matches at approximately 25,000 -yr. intervals. Spectral analysis does not indicate any significant concentrations of variance.

\section{Core 30-Late Miocene}

The similarity of color, lithology, and planktonic foraminifer content of Cores 30 and 19 would lead to the expectation of very similar benthic foraminifer content. But that is not the case; the benthic foraminiferal faunas of Core 30 continue the trend toward greater equability. Only rarely do individual species attain relative abundances of more than $15 \%$. In comparison with Core 19 ,
Ehrenbergina spp., Epistominella exigua, Pullenia bulloides, and $P$. quinqueloba are more abundant; Bulimina alazanensis, Gyroidinoides neosoldanii, and Siphotextularia sp. less so.

Q-mode varimax principal-component analysis resulted in six principal components of which only four accounted for $85 \%$ of the faunal variability, illustrating the high evenness of overall species composition. PC I is dominated by $P$. bulloides, with Globocassidulina subglobosa and $P$. quinqueloba as subordinate species. PC II is dominated by $E$. exigua with $B$. alazanensis and Siphotextularia sp. as accessory species. PC III is largely the expression of Ehrenbergina spp., with G. subglobosa being the only noteworthy secondary component species. PCs IV and V are of very low significance, accounting for 3 and $2 \%$, respectively, of the total faunal variability. PC VI, accounting for $9 \%$ of the total faunal variability, is an association of primarily Stilostomella spp., and B. alazanensis and Parrelloides bradyi as secondary members.

Examining the principal-component loadings plots and the relative-abundance plots of the species, it becomes apparent that principal-component analysis results in species associations that are weighed heavily by the covariance of salient features, if they are present, and the overall similarity in shape of the species curves. The significance of such large-scale features for the principal-component groupings apparently overrides to some extent the lower amplitude fine structure, which is clearly present in the species-abundance plots but has become "homogenized" in the principal-component loading plots.

PC I displays an overall trend of an approximately 200,000 -yr. wavelength, but only a few tentative matches of slightly more than 20,000-yr. separation can be made. Spectral analysis apparently supports this estimate by displaying peaks at a 200,000 -yr. and 20,000 -yr. periodicity, but neither is significant at the $80 \%$ confidence level. In contrast, the abundance plot of Pullenia bulloides shows a clear succession of peaks separated by about $18,000 \mathrm{yr}$. near the top, lengthening to about $20,000 \mathrm{yr}$. in the lower half of the core (Fig. 9).

PC II shows a sharp step at the 140.20 -m level and some low-amplitude 20,000-yr. oscillations in the bottom half of the core (Fig. 9). A broad 200,000-yr. to 
100,000 -yr. period high and a minor peak at a 20,000 -yr. period is indicated by spectral analysis.

PC III exhibits an overall trend from high to low and back to high loadings from top to bottom of the core. The overall record of slightly less than 200,000 yr. of this core does not permit recognition of whether this trend is half of a 400,000-yr. wavelength or not. Superimposed are oscillations that vary from slightly shorter to slightly longer than 20,000-yr. duration (Fig. 9). Spectral analysis does not indicate the presence of any noteworthy regular behavior.

PCs IV and V display high-amplitude and apparently fairly regular fluctuations, which because of their very low significance are neglected here.

PC VI again represents a case where principal-component grouping has subdued some of the lower amplitude fine structure that is present in the abundance fluctuations of its component species. Although hardly any regular behavior of the principal-component loadings curve can be discerned, neither by inspection nor by spectral analysis, several of its member species do show fairly regular oscillations of their abundance, varying between about 18,000 and 21,000 yr. in length.

\section{DISCUSSION}

The deep-water benthic ecosystem is linked to the oceans' surface in two ways: (1) Through the supply of organic matter, settling to the bottom, it is dependent upon the biological productivity of the overlying waters. For example, Lutze (1979) has shown that the bathyal and abyssal foraminiferal faunas below the highly productive upwelling system off West Africa are distinctly different from those of less productive regions. (2) Through the thermohaline circulation regime the deepwater ecosystem is linked to the process of deep-water formation which takes place in essentially only two areas, the Weddell Sea of the Antarctic and the northern North Atlantic, primarily the Norwegian-Greenland Sea.

Undoubtedly, some of the faunal variability observed within Hole $552 \mathrm{~A}$ is the result of changes of surface conditions above the site. However, the observation of drastic faunal changes during the late Quaternary in areas below the unvarying oligotrophic North Atlantic gyre, as well as in areas outside it (Schnitker, 1974), strongly suggests that on an oceanwide basis the deepwater benthic foraminiferal changes are primarily in response to changes in the thermohaline circulation regime. The subtropical gyres have been shown to remain remarkably stable during different climatic states (CLIMAP, 1976).

During the last few glacial stages, the surface conditions of the northern North Atlantic have changed drastically: the Norwegian-Greenland Sea became ice covered (Kellogg, 1976), the North Atlantic Drift of warm and saline water (a necessary precursor of North Atlantic Deep Water) repeatedly shifted to $45^{\circ}-40^{\circ} \mathrm{N}$ latitude (CLIMAP, 1976; Ruddiman and McIntyre, 1976), thus preventing or reducing the formation of North Atlantic Deep Water. It is therefore easy to see why the deep-sea environmental record is dependent upon and therefore synchronized with the Northern Hemisphere glacial and interglacial successions. Hays et al. (1976) have demonstrated the very close correlation between the timing of fluctuations of several climate indicators and the timing of insolation differences due to variations in the orbital parameters (Milankovitch hypothesis), strongly suggesting a cause and effect relationship. Pisias and Moore (1981) and Prell (1982) have shown that the $\delta^{18} \mathrm{O}$ record of late Pliocene and Pleistocene climatic fluctuations is lengthening its periodicity and amplitude with time: a prevalence of the 23,000-yr. period during the late Pliocene and early Pleistocene, an intermediate regime from about 0.9 to 1.45 m.y. ago, and the late Pleistocene (00.9 m.y. ago) in which the 100,000 -yr. cycle is dominant. On the other hand, Moore et al. (1982) noted that in the late Miocene carbonate record of DSDP Site 158 (equatorial Pacific) the variance is concentrated at a 400,000 -yr. periodicity, although periodicities of 40,000 , 22,000 , and 19,000 yr. were also present.

The record of benthic foraminifers from Hole 552A seemingly supports such evidence, although the record apparently is blemished by inaccuracies of the time scale employed. In particular the linear interpolations and extrapolations that were used to determine the timing of sample intervals made no allowance for variations of

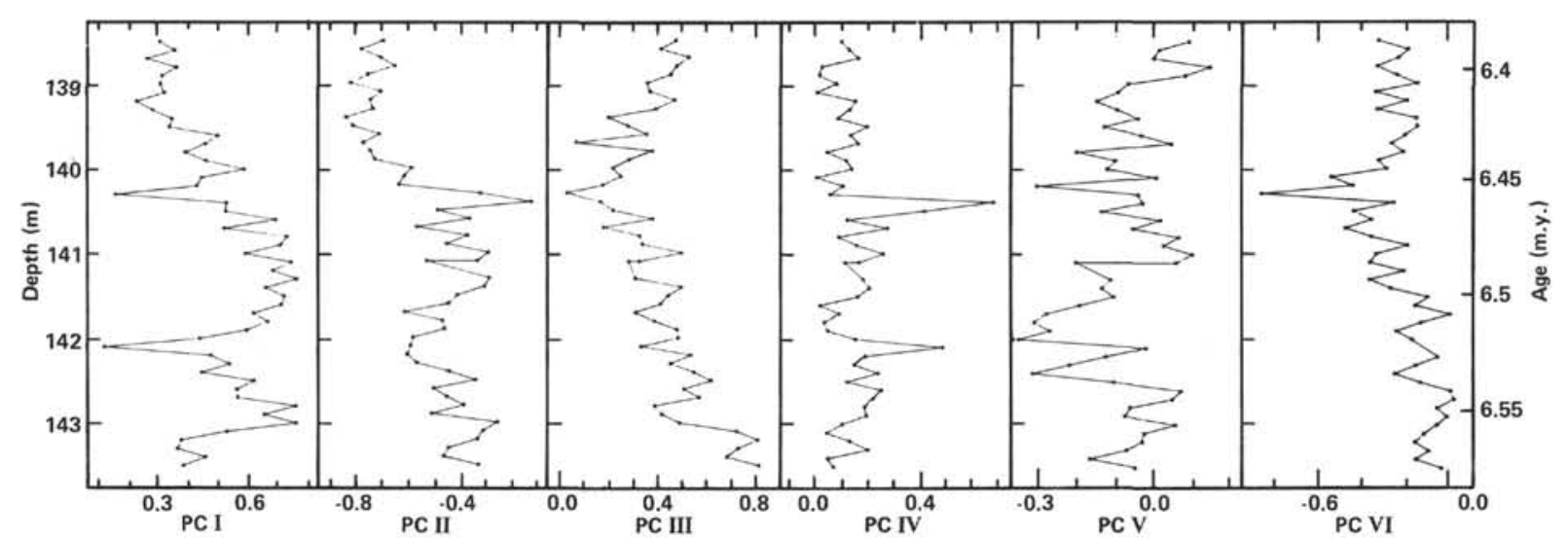

Figure 9. Downcore fluctuations of principal-component loadings representing six faunal associations within Core 30 (late Miocene). 
sediment-accumulation rates which undoubtedly are present within these cores. A strong suggestion of sedimentation rate changes lies in the frequent observation of nonstationary cycle length: a sequence of peak-to-peak matches varied by $10-15 \%$ around an average value.

The record of Core 3, early late Pleistocene in age, clearly shows a strong low-frequency signal, probably corresponding to the 100,000 -yr. eccentricity rhythm, and also clear indications of 40,000-yr. and 20,000-yr. periodicities, corresponding to the 41,000 -yr. obliquity rhythm and the 23,000-yr. and 19,000-yr. precession rhythms. The latter, because of the low resolution $(\sim 4.9$ k.y. sample interval), have merged into a single 20,000yr. cyclicity.

The longer record from the early late Pliocene of Cores 9 and 10 contains no evidence for the 100,000-yr. eccentricity cycle, but an indication of a very low frequency component of about 400,000 -yr. cycle length, suggesting that the 400,000 -yr. periodicity, observed by Moore et al. (1982) to occur in the late Miocene, occurs at the beginning of the late Pliocene as well. Both the obliquity and precession frequencies are represented in Cores 9 and 10 . The 40,000 -yr. periodicity is more obvious in Core 9 , the 20,000-yr. periodicity occurs equally in Cores 9 and 10.

Both "preglacial" cores (19 and 30 ) are too short to give any indication of the 400,000 -yr. periodicity, a lowfrequency component of about 200,000 -yr. period suggests itself, but remains uncertain. The 40,000-yr. period is completely absent from most factor-loading or species plots, and is barely recognizable in some. Only a 20,000yr. period occurs often. The amplitude of most fluctuations decreases from top to bottom, particularly in Core 30.

The shift from dominant 40,000-yr. oscillations during the "glacial" portion of the record to a dominance of 20,000-yr. oscillations in the "preglacial" record may possibly be linked to the geographic distribution of the principal influence of orbital insulation changes. As has recently been described by Ruddiman and McIntyre (in press), the 23,000-yr. precession rhythm is most notable in midlatitude records whereas the high latitudes are primarily affected by the 41,000 -yr. obliquity rhythm. For the 100,000 -yr. eccentricity and the 41,000 -yr. obliquity rhythm to become introduced into the deep-sea environment apparently some ice-related feedback mechanism is required to occur at high latitudes, presumably in the Norwegian-Greenland Sea.

The significance of the midlatitude, 23,000-yr. variability may lie in two processes. One is a simple variation in heat transfer with the North Atlantic surface circulation from mid to high latitude, which then modulates the rate of downwelling within the Norwegian-Greenland Sea. The other mechanism operates via changes in surface-water salinities of the North Atlantic brought about by variations of the evaporation rates within the midlatitude North Atlantic, but in particular in its peripheral seas, the Gulf of Mexico, Caribbean, and the Mediterranean. Variations of the salt content of North Atlantic surface waters are of great influence upon the bottom-water formation processes. Reid (1979) pointed out the importance of the Mediterranean salt contribution to global deep-water circulation. The low amplitude of the signal in Core 30 may in part result from the Mediterranean's having entered into its Messinian isolation phase at this time. It probably had ceased to be a contributor of saline water to the North Atlantic.

\section{ACKNOWLEDGMENTS}

I am indebted to Drs. Bruce Corliss, John Imbrie, Pat Lohmann, John Murray, and Warren Prell, who at various stages of this study aided with valuable criticism and advice. Thanks are due to Drs. Bruce Corliss and Tom Kellogg for reading an early version of this study. Thanks are also due Mrs. Susan Smith who typed and retyped the manuscript.

\section{REFERENCES}

Belanger, P. E., 1981. Late Cenozoic benthic foraminifera of the Norwegian-Greenland Sea [Ph.D. dissert.]. Brown University, Providence, Rhode Island.

Berggren, W. A., and Schnitker, D., 1983. Cenozoic marine environments in the North Atlantic and Norwegian-Greenland Sea. In Bott, M. H. P., Saxov, S., Talwani, M., and Thiede, J. (Eds.), Structure and Development of the Greenland-Scotland Ridge: New York and London (Plenum), pp. 495-548.

Blackman, R. B., and Tuckey, J. W., 1958. The Measurement of Power Spectra from the Point of View of Communications Engineering: New York (Dover).

Boltovskoy, E., 1980. Benthonic foraminifera of the bathyal zone from Oligocene through Quaternary. Rev. Esp. Micropaleontol., 12:283-304.

Boyle, E. A., and Keigwin, L. D., 1982. Deep circulation of the North Atlantic over the last 200,000 years: Geochemical evidence. Science, 218:784-787.

CLIMAP, 1976. The surface of the ice-age earth. Science, 191: 1131-1137.

Corliss, B. H., 1979. Quaternary Antarctic Bottom Water history: Deep-sea benthonic foraminiferal evidence from the southeast Indian Ocean. Quat. Res., 12:271-289.

Dean, W. E., Gardner, J. V., and Cepek, P., 1981. Tertiary carbonatedissolution cycles of the Sierra Leone Rise, eastern equatorial Atlantic Ocean. Mar. Geol., 39:81-102.

Ellett, D. J., and Roberts, D. G., 1973. The overflow of Norwegian Sea deep water across the Wyville-Thomson Ridge. Deep-Sea Res., 20:819-835.

Emiliani, C., 1955. Pleistocene temperatures. J. Geol., 63:538-578.

Hays, J. D., Imbrie, J., and Shackleton, N. J., 1976. Variations in the earth's orbit: Pacemaker of the ice ages. Science, 194:1121-1132.

Imbrie, J., and Kipp, N. G., 1971. A new micropaleontological method for quantitative paleoclimatology: Application to a late Pleistocene Caribbean core. In Turekian, K. K. (Ed.), The Late Cenozoic Glacial Ages: New Haven (Yale Univ. Press), pp. 71-181.

Jones, E. J. W., Ewing, J. I., and Eittreim, S. L., 1970. Influences of Norwegian overflow water on sedimentation in the northern North Atlantic and Labrador Sea. J. Geophys. Res., 75:1655-1680.

Kellogg, T. K., 1976. Late Quaternary climatic changes: Evidence from cores of Norwegian and Greenland Seas. In Cline, R. M., and Hays, J. D. (Eds.), Investigation of Late Quaternary Paleoceanography and Paleoclimatology. Mem. Geol. Soc. Am., 145: $77-100$.

Lonsdale, P., and Hollister, C. D., 1979. A near-bottom traverse of Rockall Trough: Hydrographic and geologic inferences. Oceanologica Acta, 2:91-105.

Lutze, G. F., 1979. Benthic foraminifers of Site 397: Faunal fluctuations and ranges in the Quaternary. In von Rad, U., and Ryan, W. B. F., et al., Init. Repts. DSDP , 47, Pt. 1: Washington (U.S. Govt. Printing Office), 419-431.

Moore, T. C., Pisias, N. G., and Dunn, D. A., 1982. Carbonate time series of the Quaternary and late Miocene sediments in the Pacific Ocean: A spectral comparison. Mar. Geol., 46:217-233.

Pisias, N. G., and Moore, T. C., 1981. The evolution of Pleistocene climate: A time series approach. Earth Planet. Sci. Lett., 52: $450-458$. 
Prell, W. L., 1982. Oxygen and carbon isotope stratigraphy for the Quaternary of Hole 502B: Evidence for two modes of isotopic variability. In Prell, W. L., Gardner, J. V., et al., Init. Repts. DSDP, 68: Washington (U.S. Govt. Printing Office), 455-464.

Reid, J. L., 1979. On the contribution of the Mediterranean Sea outflow to the Norwegian-Greenland Sea. Deep-Sea Res., 26: 1199-1223.

Roberts, D. G., 1975. Marine geology of the Rockall Plateau. Philos. Trans. R. Soc. London, Ser. A, 278:447-509.

Ruddiman, W. F., 1972. Sediment redistribution on the Reykjanes Ridge: Seismic evidence. Geol Soc. Am. Bull. 83:2039-2062.

Ruddiman, W. F., and McIntyre, A., 1976. Northeast Atlantic paleoclimatic changes over the last 600,000 years. In Cline, R. M., and Hays, J. D., (Eds.), Investigation of Late Quaternary Paleoceanography and Paleoclimatology. Mem. Geol. Soc. Am., 145:199-214.

, in press. Ice-age thermal response and climatic role of the surface Atlantic Ocean, $40^{\circ} \mathrm{N}$ to $63^{\circ} \mathrm{N}$. Geol. Soc. Am. Bull.

Savin, S. M., Douglas, R. G., and Stehli, F. G., 1975. Tertiary marine paleotemperatures. Geol. Soc. Am. Bull., 86:1499-1510.

Schnitker, D., 1974. West Atlantic abyssal circulation during the past 120,000 years. Nature, 248:385-387.

1979. The deep waters of the western North Atlantic during the past 24,000 years, and the re-initiation of the Western Boundary Undercurrent. Mar. Micropaleontol., 4:265-280.

1980. Quaternary deep-sea benthic foraminifers and bottom water masses. Ann. Rev. Earth Planet. Sci., 8:343-370.

Shackleton, N. J., and Opdyke, N. D., 1977. Oxygen isotope and paleomagnetic evidence for early northern hemisphere glaciation. Nature, 270:216-219.

Shor, A. N., and Poore, R. Z., 1979. Bottom currents and ice rafting in the North Atlantic: Interpretation of Neogene depositional environments of Leg 49 cores. In Luyendyk, B. P., Cann J. R., et al., Init. Repts. DSDP, 49: Washington (U.S. Govt. Printing Office), 859-872.

Streeter, S. S., 1973. Bottom water and benthonic foraminifera in the North Atlantic: glacial-interglacial contrasts. Quat. Res., 3: 131-141.

Streeter, S. S., and Shackleton, N. J., 1979. Paleocirculation of the deep North Atlantic: $150,000 \mathrm{yr}$ record of benthic foraminifera and oxygen-18. Science, 203:168-171.

Worthington, L. V., and Wright, W. R., 1970. North Atlantic Ocean Atlas (V.2): Woods Hole, Massachusetts (Woods Hole Oceanographic Institution).

Date of Acceptance: November 1, 1983

\section{APPENDIX}

Species List of Benthic Foraminifers Included in Faunal Census

Alabamina sp.

Allomorphina sp.

Astrononoin echolsi Kennett

Astrononion stelligera Orbigny

Bolivina pseudopunctata Hoeglund

Bolivina subaenariensis Cushman

Bolivinita quadrilatera Schwager

Bulimina alazanensis Cushman
Bulimina inflata Seguenza

Cassidulina teretis Tappan

Cassidulina crassa Orbigny

Cibicides io Cushman

Cibicides kullenbergi Parker

Cibicides pseudoungerianus Cushman

Cibicides robertsonianus Brady

Cibicides spp.

Dentalina spp.

Eggerella bradyi Cushman

Ehrenbergina spp.

Epistominella exigua Brady

Eponides polius $\mathrm{Phleger}$ and Parker

Eponides tumidulus Brady

Fissurina spp.

Francesita advena (Cushman)

Globocassidulina subglobosa (Brady)

Gyroidinoides altiformis (R. E. and K. C. Stewart)

Gyroidinoides neosoldanii (Brotzen)

Gyroidinoides orbicularis (Orbigny)

Hopkinsina sp.

Hoeglundina elegans (Orbigny)

Lagena spp.

Laticarinina pauperata (Parker and Jones)

Lenticulina spp.

Loxostomum truncatum

Melonis barleeanum (Williamson)

Melonis pompilioides (Fichtel and Moll)

Nonionella spp.

Oolina spp.

Oridorsalis tener (Brady)

Oridorsalis umbonatus (Reuss)

Osangularia umbonifera (Cushman)

Parafissurina spp.

Parrelloides bradyi (Trauth)

Planulina wuellerstorfi (Schwager)

Pleurostomella spp.

Pullenia bulloides: Orbigny

Pullenia quinqueloba (Reuss)

Pullenia sp.

Pyrgo murrhina (Schwager)

Pyrgo elongata (Orbigny)

Quinqueloculina spp.

Sphaeroidina bulloides Orbigny

Sigmoilina tenuis (Czjzek)

Sigmoilopsis schlumbergeri (Silvestri)

Siphonina tenuicarinata Cushman

Siphotextularia catenata (Cushman)

Stainforthia spp.

Stilostomella spp.

Textularia spp.

Trifarina angulosa (Williamson)

Trifarina bradyi Cushman

Triloculina frigida Lagoe

Uvigerina auberiana Orbigny

Uvigerina peregrina Cushman

Valvulineria laevigata Phleger and Parker 